\title{
建築くい基礎における新耐震設計法 適用の動向とその問題点
}

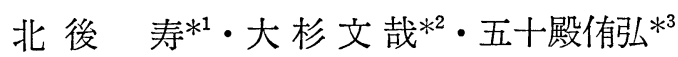 \\ 野村 進*4
}

\begin{abstract}
概 要 建築基礎の耐震設計については, 上部構造のように新耐震設計に扔ける一次設計と二次設計の区別がなく，たて まえ上は一次設計の段階でいいとされている。しかしくい基礎は, 直接基礎と異なり上部構造と接合するくい材を有する構 造となっており，基礎とくいの接合法によっては直接的に上部構造の影響を受けるわけである。本稿は，このような建築く い基礎の設計に関し，実務者による実際の設計例を通して，それに対処している現状と問題点について 解説するものであ る。 キーワード : くい基礎, 耐震設計, 水平抵抗, 液状化
\end{abstract}

はじめに

耐震設計における建築物基礎の位置づけについては, 先年建設省が住指発 324 号通達で公けにした「地震力 に対する建築物の基礎の設計指針」の総則に示された， つぎの表現が非常に適切であると考えている。

「地震力を受ける建築物の基礎は，上部構造と同等も しくはそれ以上の構造安全性を保持するように設計かつ 施工され福ばならない。また, 基礎は常に地盤と接して いる構造部分であることを勘案し，液状化，地すべり， 地盤面の沈下等, 地震時に地盤変動が生じるおそれのあ る場合には，これらについての安全性の検討を別途に行 い，かつ必要に応じて対策を講ずることとする」

本稿ではくい基礎を論ずることになるが，構造安全性 に関する基本思想は，この文章に表されたものと全く同 じである。ご承知のように, 昭和 56 年建築基準法同施 行令の大改定が行われ，耐震設計関しいわゆる “一次 設計と二次設計”が区分けされることとなった。

上部構造ではすでに，かなり詳細にわたり二次設計に ついての具体的手法が示されてきたが, 基礎構造では地 盤把握の難しさから，いまだ検討段階を脱し切れていな い。ここでは実務的な設計例を通して，建築くい基礎の その後の前進と問題点を披露するものである。

$* 1$ 日本工業大学教授 (棈造家懇談会技術委員会地盤基礎部会前主査)

$* 2$ (株) 久米建築事務所構造設計室課長代理 (同上部会委員)

$* 3$ 鹿島建設(株)建築設計本部設計部技術長 (同上部会委員)

$* 4$ 三菱地所(株)第 3 建築部参事 (同上部会委員)

*5 (株) 日建設計東京本社構造部構造設計主管 (同上部会委員)

\section{1.くい基礎の耐震設計}

建築基礎の構造設計は, (社) 日本建築学会の「建築 基礎構造設計規準・同解説」(昭和 49 年 11 月版。現在改 訂作業中で近く新版になる予定）を，標準的参考文献にして 行われてきた。そしてすでに現行のものに，水平力に対 するくい基礎設計に関する規定は条文化されている。

しかし, 宮城県沖地震 (昭和 53 年), 浦河沖地震 (昭 和 57 年) と相次ぐくい基礎の被害が表面化するに至り， 冒頭に記したように，建設省は急きょ「地震力に対する 建築物の基礎の設計指針」を制定することとなり，昭和 59 年 6 月公刊した。

この指針の内容は，ほとんどがくい基礎設計に関係あ るものとなっており, 主要点を列挙すると以下のとおり である。

1）〈い基礎における基礎スラブ根入れ効果による水 平力の低減

2) 鉛直支持力, 引抜き抵抗力, 水平耐力に対する新 たな提案を含めた計算式による検討

3）〈い断面に対する弾性複合応力度の計算式の提案

4）耐震的に最も大きな問題になっている，くいの水 平抵抗力の検討について

(1) くい頭固定度の概念の導入

(2) コンクリート系くい断面の設計用せん断力を分 担水平力の 1.5 倍の值とする考え方

5) 〈い材の許容応力度につき, 材料安全率, 施工要 因, 荷重変動要因等を総合的に判断した検討結果の 採用 
6）〈い頭接合部の設計，〈い頭処理に関する施工上 の注意規程

本指針の内容からみて, 建設省は構造設計者の自主的 判断を尊重する立場をとっているので, 設計者の自由な 発想と責任が重んじられているわけである。たとえば, くい頭処理では, 原則的には固定としながらも, 接合詳 細に対応した固定度に基づく設計計算が行えるようにな っており，今後の研究を待っといら態度が表明されてい る。

\section{2.〈い基礎について解明すべき事項}

本題に関連して, 本誌昭和 59 年 10 月号に, 建築研 究所杉村義広氏が, 基礎構造全体の問題点について主要 事項を指摘されているので，この中からくい基礎に関連 するものを拔粋してみよう。

1）地盤評価について, 水平地盤反力係数, 〈い先端 支持力および周面摩擦力, 液状化層などが重要項目 となる。

2) くい材の構造性能では, 終局耐力と勒性, 塑性化 過程の影響, せん断性状, 局部座屈性状, 構造特性 係数など多くの未解明点がある。

3) 〈い頭接合部については, 固定度, 中詰めコンク リートの影響, カットオフの影響, 基礎ばり・柱と の剛度の相関などもこれから引き続いて検討すべき 対象である。

また一般的な事柄として，つぎのようなことも明確化 すべき大きな問題点としている。

1）耐震性能に関する上部構造との関係

2）地震時の入力関連一一水平力の分担, 液状化によ る影響, 地下構造物の外力分布（深さ方向）

3）崩壊形（破壞形式）の分類

4）構造計画におけるくい基礎の配置(とくに隅角部)

5）地盤一基礎一建物系の解析法の確立

これらはそれぞれ重要な研究事項であり, 今後の基礎 構造に関係ある研究者, 技術者の研鑚に待つ所大と考元 られる。

\section{3. くい基礎設計の耐震的問題}

前項で具体的なくい基礎に関する今後の検討テーマに ついて記したが, 紙数の都合でその詳細の説明を省かざ るを得なかった。ここでは，このような現状を反映して 昨年 (昭和 60 年) の日本建築学会の年次大会で行われ たパネルディスカッションでのテーマとその概要を紹介 しよう。

このディスカッションの主題は「くい基礎の耐震設計 上の諸問題」であり, テーマは 5 つ分かれ, “既製コ ンクリートぐいの勒性と 耐力”, “水平地盤反力係数”, “くい頭接合部の耐力”，“短ぐいの水平耐力”，“くい基 礎に及ぼす液状化の影響” であった。これらのテーマ は, 前項で指摘した未解明事項の中で, 実際設計上とく に必要性が痛感されているものである。

これらについて, 建築雑誌に公表された内容などを中 心に要約すると次のようになる。

（1） 既製コンクリートぐいの勒性と耐力

くいは地震時に鉛直方向のみならず横方向力も受ける ため, 通常くい頭部では, 軸力, せん断力, 曲げモーメ ントが同時に作用する複合応力状態となる。現状では， くい材の耐力以上の地震力が作用した場合のくい頭部の 挙動についてはまだよく分かっていない。

くい基礎の極限状態を想定したとき，〈い材自体の勒 性と耐力が非常に重要な問題となってくる。宮城県沖地 震で数多くの被害を受けた高強度 P C ぐい（PHC ぐい） について，そのくい種ごとに勒性と耐力度および地盤中 の挙動を実験的に確かめた結果が今回発表された。

これによると, 軸力を考慮したくい頭固定の水平載荷 試験では, 弾性域においては軸力の影響はないといって いいが, 塑性域においては軸力により脆性的圧縮せん断 破壊が生じることが確かめられた。

\section{（2） 水平地盤反力係数}

弾性支承梁法の解析に おいて, 水平地盤反力係数 $k_{h}$ の妥当な評価は極めて重要である。 $k_{h}$ に影響する因子 としては, (1)地盤の非線形性, (2)くい径, (3)載荷速度,

Present Situation and Problems on Aseismic Design of Pile Foundation

By H. Hokugo, F. Ohsugi, A. Omika, S. Nomura, Y. Fukuda

Concrete Journal, Vol. 29, No. 8, pp. 4 12, Aug. 1986

Synopsis The pile foundation is different from mat foundation in the view point of using the pile material connected with upper construction. So that is directly affected by the behavior of the main building structure and there are many difficult problems on aseismic design about it. This report shows about 4 present pile. foundation examples for structural limited design of building under large earthquake, through the practical business by some technical experts.

Keywords : pile foundation, aseismic design, lateral resistance, liquefaction 
(4)繰返し載荷，(5)施工法，などがある。

$k_{h}$ を求內る方法としては, (1)水平載荷試験, (2)地盤 調查の 2 つがある。(2にについて多数の提案がなされてい るが，得られる值は必ずしも一定のものでなく，かなり の幅がある。したがって,これらの推定法をいかに現実 設計に利用するべきか, また, これと水平載荷試験結果 との対灾を明確にする必要があると考えられる。

(3) くい頭接合部の耐力

くい頭接合部は, 地震による変動軸力, 水平力が作用 し，予想外の過酷な応力状態となる部分である。

過去においてピン支持との仮定のもとに安易に設計し てきたのが，固定を原則とする考え方に変わってきた。

くい頭部分に生じる耐力, 変形については幾多の実験 研究がなされている所である。

くい頭を鋼管巻き補強したものが，最も固定度が高い という実験報告もあるが，この問題は上部構造の耐震設 計とくいの水平耐力に関連ある, いわゆる建物一基礎一 地盤系解析の一環としてとらえていくべきであろうとい うことになる。

\section{（4）短ぐいの水平耐力}

短ぐいは, 先端固定だと变位が小さく, せん 断力が支配的になるが，先端ピンでは長ぐいと そう変わらない。水平時挙動は, このように 長・短による差が大きく, 注意すべきである。

傾斜地盤は最近の造成地に多くなってきてい るが, 各くいの荷重分担率, ねじれ変形など, 一般的な水平地盤での長いくいに比べ, 長短混 在の影響は全体的な耐力低下につながるようで ある。

短ぐいの強震時の挙動を考えた場合, その終局耐力 は，おろそかにできない大事な実務的課題といえよう。

（5）〈い基礎に及ぼす液状化の影響

液状化が予想される地盤では, 地盤改良対策を講じる 必要がある。しかしくい基礎の場合, その対策なしにく 、築造がなされ, 地震時の $k_{h}$ の変動が問題となってく ることがある。それとともに液状化の地域差, 地表面最 大加速度も関係してこよう。

したがって, このような地盤では, 液状化のメカニズ ムに即したくい基礎への入力とその応力変動を明らかに することにより，〈い基礎設計の合理化をはかっていく ことが今後の課題である。

このディスカッションには, 会場にあふれるほどの 300 人以上の関係者が参加し, 時宜を得たこの種問題に ついての関心の深さが示されたわけで, 非常な盛会裏に 終わったことを付け加えておく。

\section{4.くい基礎の最近における設計例}

ここに示すものは, 実務家によって最近設計された建 築くい基礎の実例である。提出された原稿は精粗入り交 じってはいるが，担当者の原案を尊重し，ほとんど修正 を加えずに揭載することにした。

既製コンクリートぐいの中掘工法 1 例, 同法拡底ぐい 1 例, 場所打ちコンクリートぐい払頭工法 1 例, そして 建物全体の二次設計と関連つけたたくい基礎設計 1 例の合 計 4 例の内容を紹介する。

\section{1 既成コンクリートぐい中掘工法}

建物は地上高さおよそ $25 \mathrm{~m}$ の比較的荷重の大きい中 層建物であり，上部構造は R C 造である。

主な地盤柱状図および土質定数を図一1.1 および1.2 に示す。建物は, GL 約 $-33 \mathrm{~m}$ 付近の堅固な細砂層に 既製コンクリートぐい（ACぐい）にて支持されてい る。基礎およびくいの概要は, 図一1.3 のとおりであ る。地盤の概要は, 支持層はほぼ水平に分布している が, 中間層は軟弱なシルト層, 比較的中位の洪積砂層,

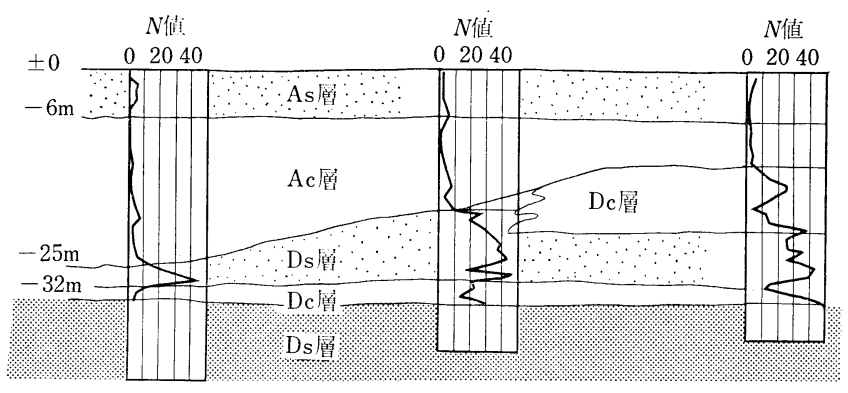

図一1.1 地質断面図

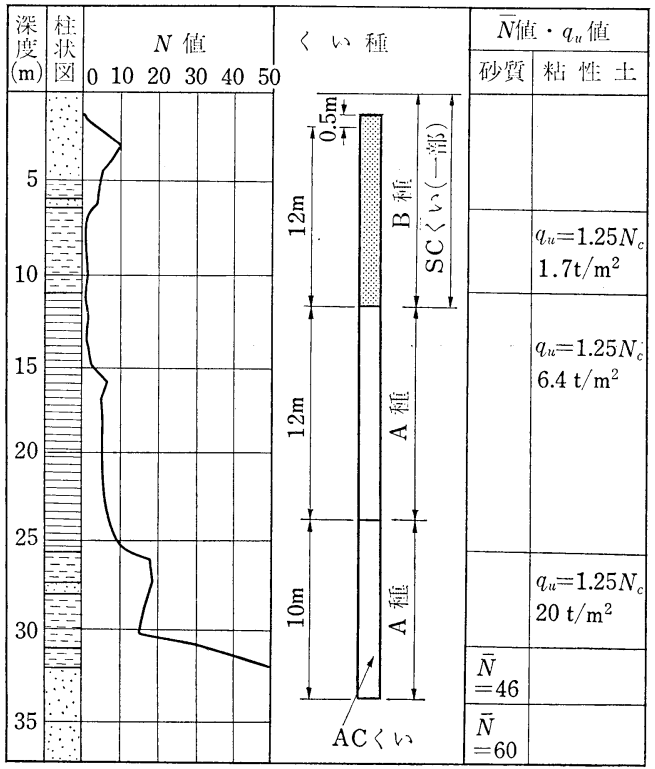

図一1.2 地盤柱状図 


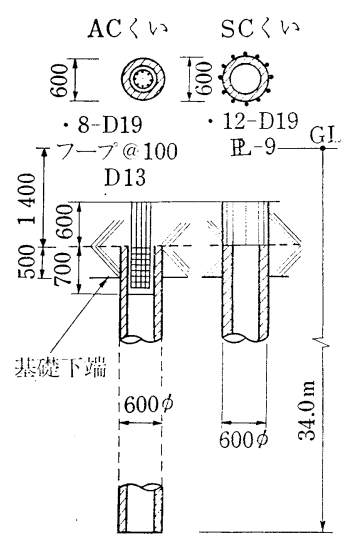

$\mathrm{AC}$ いプレストレス B種 $80 \mathrm{~kg} / \mathrm{cm}^{2}$ A種 $55 \mathrm{~kg} / \mathrm{cm}^{2}$

図一1.3基礎およびくい 概要
およびシルト層からなる。 洪積層は敷地の半分程度に 傾斜して分布している。水 位は $\mathrm{GL}-2 \mathrm{~m}$ から $-3 \mathrm{~m}$ くらいにある。上部には砂 層が, GL $-5 \mathrm{~m}$ から $-6 \mathrm{~m}$ 付近に, ほぼ水平に分布し ている。この砂層は, 地盤 調査結果から, 地震時に液 状化のおそれは少ないと報 告されている。

くいの設計は, くい頭固 定とし, 上ぐいをB種, 中 ぐい下ぐいを $\mathrm{A}$ 種として水 平力に対処した。くい頭固 定にするため，〈いを基礎 内に $50 \mathrm{~cm}$ ほど貫入した。 また, 水平力による軸力を考慮し, 下ぐい $\mathrm{A}$ 種のプレス トレスを割増ししている。地震時のくい頭の曲げモーメ ントは, すべて基礎ばりで負担できるようにした。支持 力は, 打込みぐい算定式, 〈い材の強度, 行政指導等を 考慮して，長期許容設計支持力として， $\phi 600$ で 160 t/本とした。設計時のくい施工法は, プレボーリング併 用の油圧ハンマーによる先端打込みぐいであったが, 試 験ぐいを実施したところ，プレボーリングを行ったにも かかわらず洪積層の中間砂層で止まり, 所定の深さまで 達せず貫入不能になったので, 施工法を変更して中掘式 最終打撃工法とし, 再度試験ぐいを実施した。この結 果, くいは所定の支持層に貫入することができ, 支持力 も確認できた。中掘り式のためくい先端が開放状態にあ り, 砂層内貫入によるボイリングに対しても打撃試験を 行い, 問題ないことを確認した。また, 建物の片側が比 較的海に近いので, 地震時の土の移動を考慮して, 海に 近い側の上ぐいを $\mathrm{SC}$ ぐいとし, 地震時の水平抵抗を割 增しした。

このほか, 打込みによる偏心の考慮, 軟弱層内に貫入 する場合の土砂のくい内への侵入による内圧増加に伴う ひびわれ, 打込み中の縦割れ, くい先端の破損等を十分 注意しながら施工した。前述したように, 立地条件と施 工性を十分加味し, 設計は一応一次設計によっている が，二次設計の精神を極力取り入れたつもりである。

くいの二次設計上, 注意を要することは, できうる限 り多くの情報を基にして検討する必要があるということ である。

この例の場合，〈いの設計上, 特記する事項として,

1）立地拉よび設計条件により，くい工法を選定す る。
2）少ない地盤調查結果を基に，近隣資料，関連する 文献等により，設計上の諸係数を算定する。

3）〈いの鉛直・水平等の耐力は, 各種指針に示され た算定式によった。

4）砂地盤の液状化の検討は簡易法によって行った。

5）〈い工法は，施工試験で調整した。

6）負の摩擦力も考慮した。

等である。

このように一例をとってみても, くいの設計は, 地盤 特性と施工性によるところ大である。

二次設計の判断材料を得るには，

1）精度のある調查, 例えば動的三軸試験, PS 検層

2）多くの実験データおよび実測データ

3）鉛直，水平，引抜き等の載荷試験

4）各種施工試験

等が必要と考えられるが，いずれの場合も多額の費用と 時間を要する。したがって当面は, わかる範囲で建設地 の地盤特性を調查し, 施工試験等から設計へのフィード バックにより，広い意味での妥当性を見いだし，試行錯 誤で検討を進めた後に設計条件を整理すれば, 二次設計 の検討の意味があると考えられる。また，下部構造の設 計は予期せぬ事態が発生すること（例えば大地震時での 地盤の変動）をある程度予想して設計したい。

\section{2 既成コンクリートぐい中掘工法（拡底）}

本設計例は，既設建物を取り壊して新設建物を設計す るにあたり, 既設ぐいが深さ $60 \mathrm{~m}$ に設置されているた め，既設ぐいを現存させたまま新設ぐいを打設したもの である。

(1) 建 物 概 要

建物名称 : 倉庫

建物規模 : SRC 造地上 5 階建て, 塔屋 1 階

基礎型式 : 独立基礎の FPHC ぐい ( $\phi 800)$ 中掘り拡 底工法

(2) 敷地地質

敷地は湾岸の運河に近接し, 特徵として沖積堆積土の 発達がとくに著しく, 軟弱性の粘性土層が $50 \mathrm{~m}$ 近くの 層厚で分布している。地質の構成を図一2.1 に示す。

\section{（3）基礎型式の選定}

当敷地には既設建物の P C ぐいが $60 \mathrm{~m}$ の支持層まで 多数打設されており，既設ぐいの引抜き工事は施工上可 能ではあるが，工事費が多額である上に施工日数も多い ため,くいは現存させたまま新設くいを設計することと した。

新設建物は 5 階建ての 倉庫で 積載荷重は 500 1 000 $\mathrm{kg} / \mathrm{m}^{2}$ と重く, 標準的な柱軸力は中柱 $610 \mathrm{t}$, 側柱が $480 \mathrm{t}$ とかなり大きい。したがって，一般的には大口径 の場所打ちぐいが適当であるが，既設ぐいと重なる箇所 


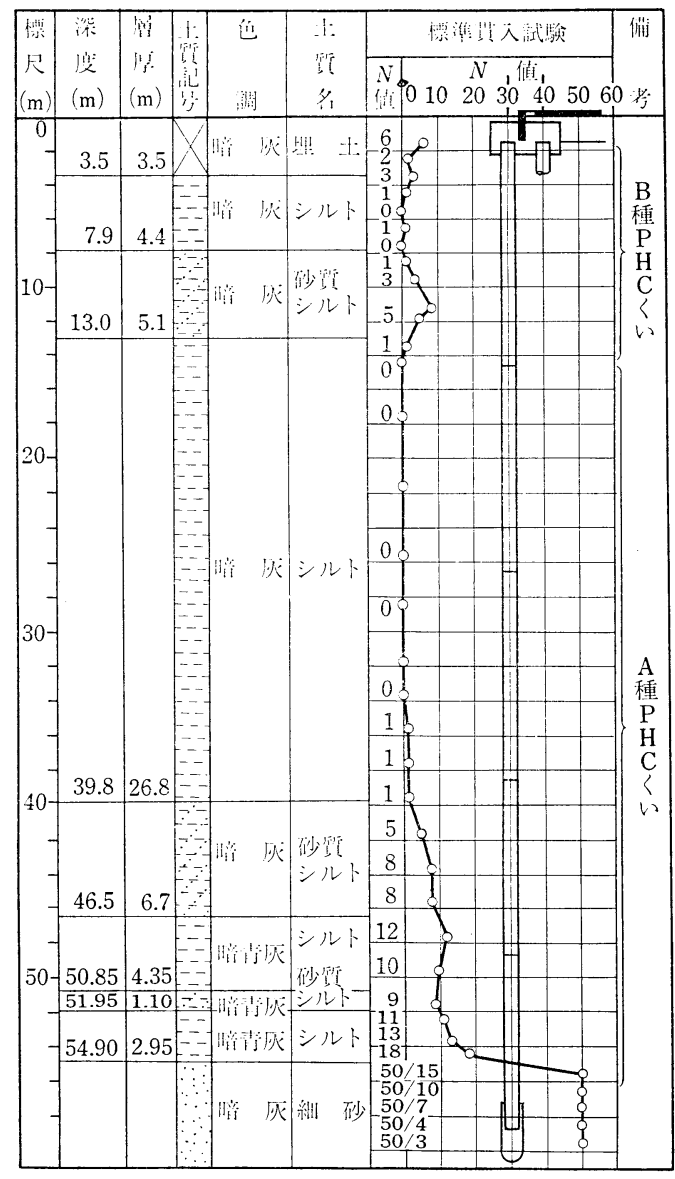

図一2.1 土質柱状図
が多く，偏心させても基礎ばりで処理しきれないため， 既製ぐいとした。支持層が哚く，施工時の騒音振動障 害対策も考慮する必要がある等の理由で, 最終的には PHC ぐいを採用し，工法は PHC ぐいの中空部に特殊 ビットを取り付けたスクリュー式オーガーを挿入して， くい先端部の直下を掘削・排土しながらくいを埋設す る, いわゆる中掘り工法で, 支持力発現方法としては支 持地盤中に先端根固め球根を造成する方法をとった。

(4) くいの設計

PHC ぐいは, くい径 $\phi 800$, くい先端位置は GL -58 $\mathrm{m}$ とし，その構成は上ぐいを $\mathrm{B}$ 種 (長さ $13 \mathrm{~m}$ ), それ 以下は 10 12 $\mathrm{m}$ の $\mathrm{A}$ 種を 4 本継ぎとした。くいは柱軸 力に応じて本数を決定した。くいの配置の概要を 図一 2.2 亿示す。また，敷地地盤が軟弱な地層で地下室もな いので，〈いの水平抵抗性能を確保するためにくい頭を $1 \mathrm{D}$ 基礎に埋め込ませ，図一2.3 のようなディテールと した。くいの詳細設計を以下に示す。

(5) 鉛直支持力

1)〈い先端支持力から決まるくい耐力

支持力算定にあたり, 安全をみて砂層の先端支持力の みとする。

$$
\begin{aligned}
P_{a} & =\frac{1}{3}\left(25 \cdot \bar{N} \cdot A_{p}\right)=\frac{1}{3} \times 25 \times 50 \times 0.5027 \\
& =209 \mathrm{t} / \text { 本 }
\end{aligned}
$$

2) 材料強度から決まるくい耐力

$$
\begin{aligned}
P_{a} & =f_{c} \cdot A_{c} \cdot \eta=200 \times 2.384 \times(1-0.5 \times 4) \\
& =381 \mathrm{t} / \text { 本 }
\end{aligned}
$$

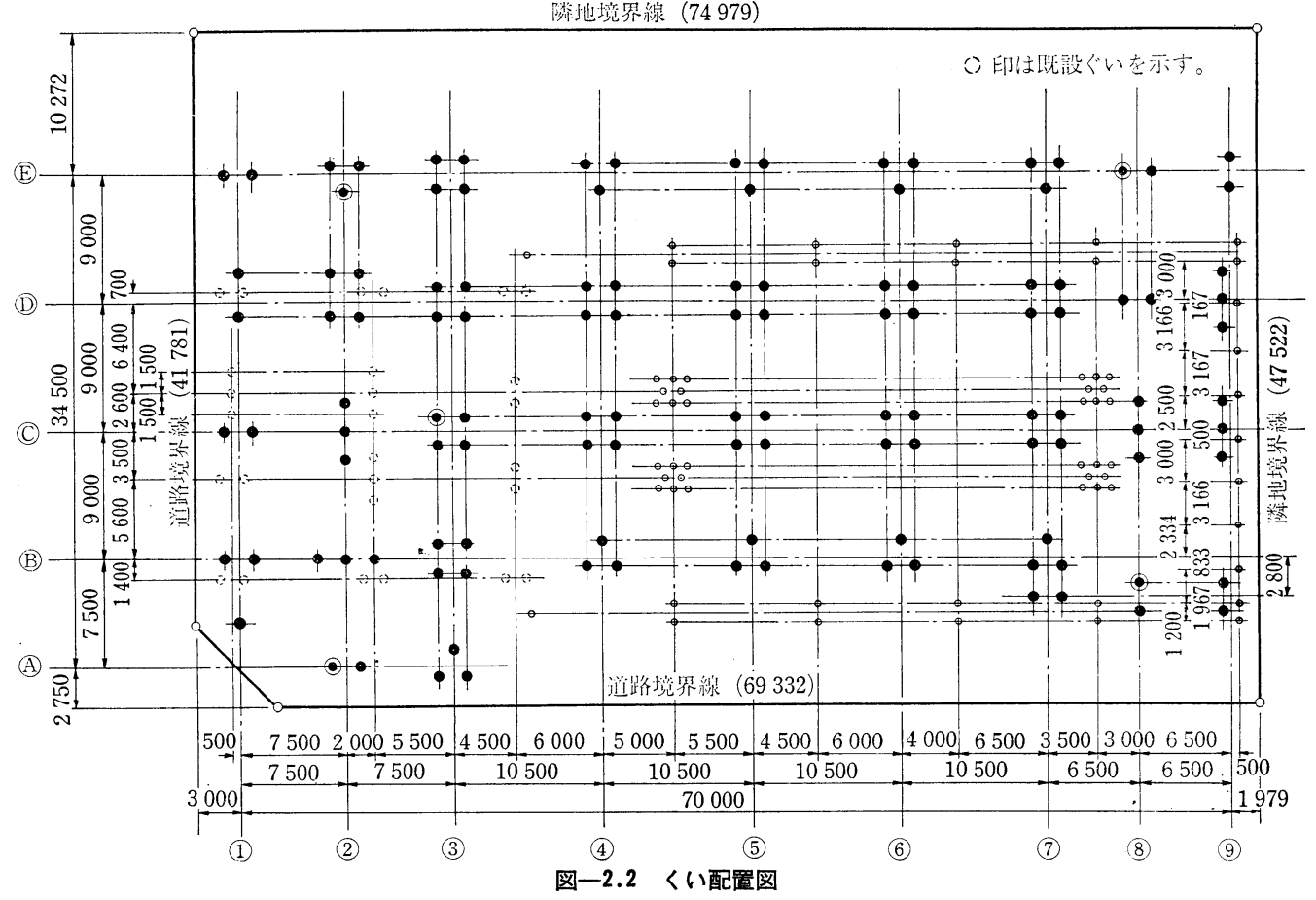




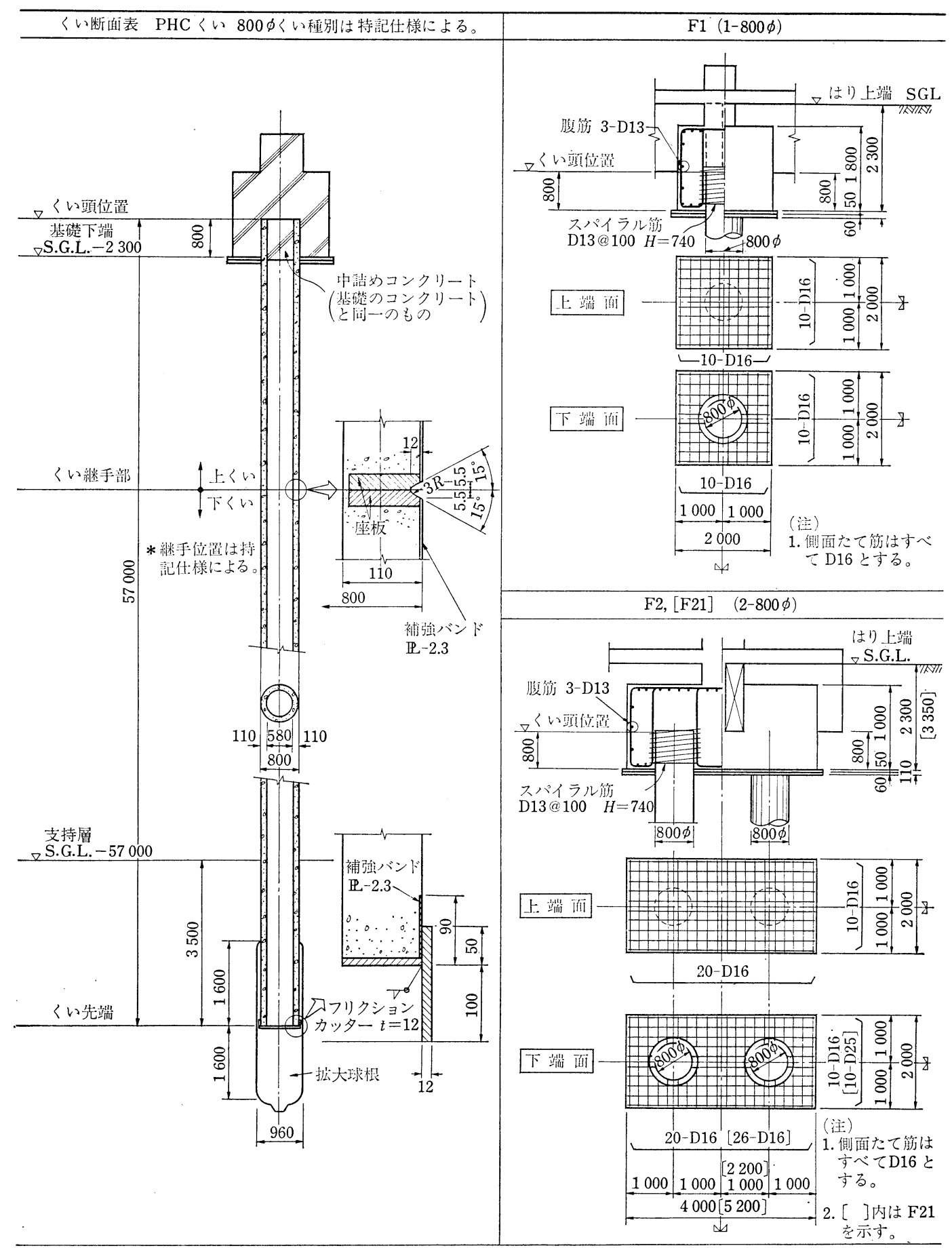

図一2.3 くいおよび基礎断面表

3) 負の摩擦力

負の摩擦力の作用する層は $\mathrm{GL} \pm 0$ から $-30 \mathrm{~m}$ の 範囲とする。

$$
\begin{aligned}
P_{F N}=0.8 & \times 3.14 \times\{0.3 \times 0.5 / 2+(0.3+6.2) \\
& \times 29.5 / 2\}=241.0 \mathrm{t}
\end{aligned}
$$

$$
\begin{aligned}
P+P_{F N} & =209+241=450 \mathrm{t}<a_{p \cdot s} f \\
& =2.384 \times 800 / 2=954 \mathrm{t} \quad \mathrm{OK} \\
P+P_{F N} & =450 \mathrm{t}<\left(R_{U P}+R_{F}\right) / 1.2 \\
& =628 \mathrm{t} / 1.2=523.0 \mathrm{t} \quad \text { OK }
\end{aligned}
$$


（6）地震時水平力に対する検討

くい1本当りの水平力 $Q=2214 \mathrm{t} / 117$ 本 $=18.9 \mathrm{t} /$ 本 水平方向地盤反力係数

$$
\begin{aligned}
k_{h} & =0.8 \times E_{0} \cdot B^{-3 / 4}=0.8 \times 7.0 \times 80^{-3 / 4} \\
& =0.21 \mathrm{~kg} / \mathrm{cm}^{3}
\end{aligned}
$$

倸数 $\beta$ の算定

$$
\begin{aligned}
\beta & =\sqrt[4]{\frac{k_{h} \times B}{4 E I}}=\sqrt[4]{\frac{0.21 \times 80}{4 \times 4.0 \times 10^{5} \times 1.54 \times 10^{6}}} \\
& =1.62 \times 10^{-3} \mathrm{~cm}^{-1}
\end{aligned}
$$

- くいの応力

くい頭固定として, Y.L. Chang の式により，

$$
\begin{aligned}
M_{0} & =\frac{Q}{2 \beta}=\frac{18.9 \times 10^{3}}{2 \times 1.62 \times 10^{-3}} \\
& =5.83 \times 10^{6} \mathrm{~kg} \cdot \mathrm{cm}=58.3 \mathrm{t}-\mathrm{m} \\
M_{\max } & =\frac{0.104}{2} \times M_{0}=1.21 \mathrm{~kg} \cdot \mathrm{cm}=12.1 \mathrm{t} \cdot \mathrm{m} \\
L_{m} & =\frac{1.571}{\beta}=970 \mathrm{~cm}
\end{aligned}
$$

-くいの応力度の検討

設計用軸力 $N=194 \pm 114=308.0 \mathrm{t}, 80.0 \mathrm{t}$

設計用曲げモーメント $\quad M=58.3 \mathrm{t}-\mathrm{m}$

検討は次式による。

$$
-f_{b} \leqq \frac{N}{A_{e}}+\sigma_{e}+\frac{M}{I_{e}} y \leqq f_{c}
$$

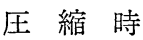

$$
\begin{aligned}
& \frac{308 \times 10^{3}}{2461}+80+\frac{58.3 \times 10^{5}}{1.538 \times 10^{6}} \times 40 \\
& =357 \mathrm{~kg} / \mathrm{cm}^{2}<f_{c}=400 \mathrm{~kg} / \mathrm{cm}^{2} \quad \text { OK }
\end{aligned}
$$

引抜き時

$$
\begin{aligned}
\frac{80 \times 10^{3}}{2461} & +80-\frac{58.3 \times 10^{5}}{1.538 \times 10^{6}} \times 40 \\
& =-39.1 \mathrm{~kg} / \mathrm{cm}^{2}>-f_{b}=-40 \mathrm{~kg} / \mathrm{cm}^{2}
\end{aligned}
$$

$\mathrm{OK}$

・せん断力に対する検討

検討は次式による。

$$
\begin{aligned}
\tau_{\max } & =\frac{Q_{D} \cdot S_{0}}{2 \mathrm{t} I} \leqq \frac{1}{2} \sqrt{\left(\sigma_{g}+2 \sigma_{d}\right)^{2}-\sigma_{g}{ }^{2}} \\
\sigma_{g} & =\sigma_{e}+\sigma_{L}, \quad 80+\frac{80 \times 103}{2461}=112 \mathrm{~kg} / \mathrm{cm}^{2} \\
\sigma_{d} & : \text { コンクリートの許容斜張応力度 } \\
\sigma_{e} & : \text { 有効プレストレス }\left(\mathrm{kg} / \mathrm{cm}^{2}\right) \\
& \sigma_{L}: \text { 長期軸応力度 }\left(\mathrm{kg} / \mathrm{cm}^{2}\right) \\
Q_{D} & =1.5 \times 19=28.5 \mathrm{t} \\
S_{0}= & \frac{2}{3} \times\left(r_{0}{ }^{3}-r_{i}^{3}\right)=\frac{2}{3} \times\left(40.0^{3}-29.0^{3}\right) \\
= & 2.64 \times 10^{4} \mathrm{~cm}^{3} \\
\tau_{\max }= & \frac{Q_{D} \cdot S_{0}}{2 t I}=\frac{28.5 \times 10^{3} \times 2.64 \times 10^{4}}{2 \times 11 \times 1.538 \times 10^{6}} \\
= & 22.2 \mathrm{~kg} / \mathrm{cm}^{2}
\end{aligned}
$$

$$
\begin{aligned}
\frac{1}{2} & \sqrt{\left(\sigma_{g}+2 \sigma_{d}\right)^{2}-\sigma_{g}{ }^{2}} \\
& =\frac{1}{2} \sqrt{(112+2 \times 18)^{2}-112^{2}} \\
& =48.5 \mathrm{~kg} / \mathrm{cm}^{2}>\tau_{\max } \text { OK }
\end{aligned}
$$

くいと基礎の接合部の設計は, くい頭に生じる曲げモ ーメントを基礎フーチング内に埋め込んだ部分の曲げね ビり抵抗力で基礎，基礎ばりへ伝達させる。

\section{3 鉄筋コンクリート場所打ちぐい（拡頭）}

この例は, 上部構造は高さ $31 \mathrm{~m}$ 以下の地下なしの $\mathrm{SRC}$ 造である。下部構造はアースドリルぐいで, GL 約 $-35 \mathrm{~m}$ 以深の砂䃯層で建物を支持している。

地盤柱状図は 図一3.1のように, 中間層は軟弱な冲積 層であり，地表面近くには，ゆるい砂層が分布する。水 位は $\mathrm{GL}$ 一約 $1.5 \mathrm{~m}$ 付近で, 静水圧分布をしており, この砂層は地震時に液状化の恐れが高いと報告されてい る。建物は平面的に小さく，塔状建物化近い。支持層か ら建物の軒の高さまで, 全長でおよそ $70 \mathrm{~m}$ くらいにな り, 東京周辺で見られる比較的多い中層建物の例であ る。

くいの設計は，建物に地下室がないため，できるだけ 基礎を深く（GL 約 $-3.0 \mathrm{~m}$ ）し，基礎ばりの剛性を高 めてある。

くいの水平力に対する検討は, 上部砂層の横抵抗を無 視した結果, 支持力によるくい径では設計できず，その 対策として, くい頭部約 $10 \mathrm{~m}$ を拡頭し, 水平抵抗を増 大させた (粘性土に約 $3 \mathrm{~m}$ 拡頭部を貫入)。粘性土の横

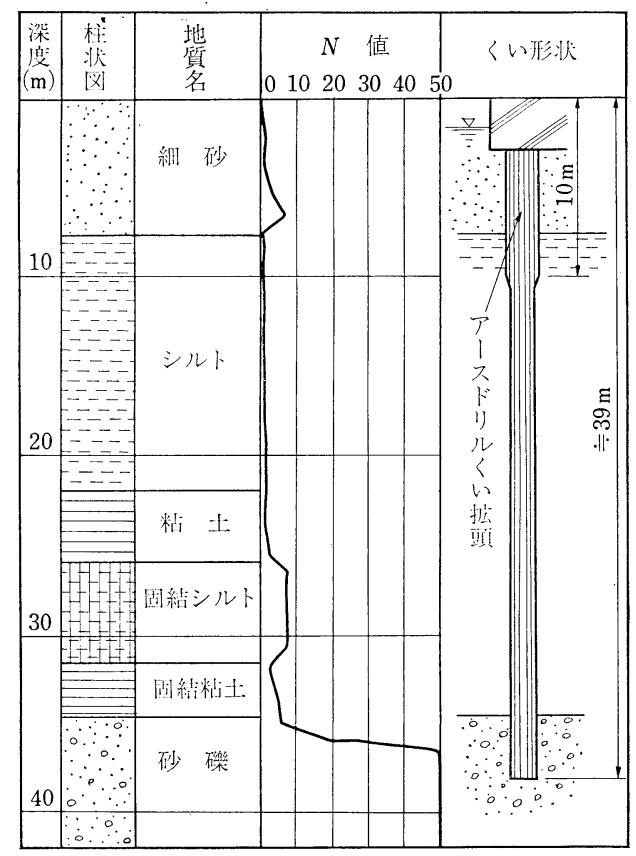

図一3.1 地盤柱状図 

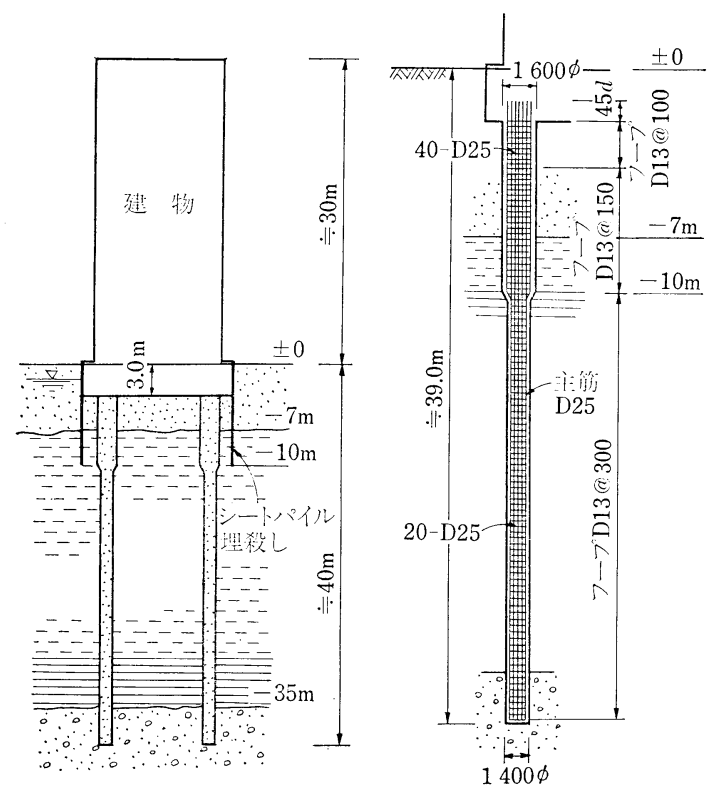

長期設計耐力 $325 \mathrm{t} /$ 本

\section{図-3.2 基礎関係図}

抵抗は測定値から推定した。くい頭は固定とし, 地震時 のくい頭の曲げモーメントは, すべて基礎ばりで処理し た。

このように液状化の恐れのある地盤に対しては, くい の変位量を極力少なくするために,

・基礎ばりの剛性を増大する。

・基礎関倸の重量を増し，極力引抜き力を生じさせな いようにする。

・くい頭を固定にする。

・土の移動を防止するよう工夫する (山留め利用, 地 盤改良等)。

・せん断破壊しないよう，フープで補強する。

等が考えられる。

このほか, 応力上, 上部構造からの軸力をどのように
において基礎が深いためシートパイルで山留めして基礎 工事が終了したが，近隣の状況からシートパイルをその まま残したところ，これが地震時の液状化対策の一助と なった。

施工試験では，ほぼ設計に沿った施工の確認ができ た。基礎関係の概要は 図一 3.2 による。

場所打ちコンクリートぐいの場合, とくに注意する点 は,

1）支持層が深く目視で確かめられないので，超音波 探傷の孔壁測定，検尺による先端スライム量の測定 を実施する。

2）中間層がボイリング等でゆるむことがある。

3）先端まで上部荷重が伝達せず，ほとんど摩擦で抵 抗しているのが実状である。

4) 実際の耐力は不明確であるが, 計算上, 条件を仮 定して, 鉛直耐力, 水平耐力, 引抜き耐力を求めて いる。

等であるが, 設計上は, 非常に少ない資料によって耐力 を決めざるを得ない。2 次設計上の各種定数の考え方に ついても十分整理して, 方向性を見誤らないようにした い。そのため, 今後二次設計を行う場合, 例えば上部構 造と同様, 規模別, 構造別, 形状別, 工法別等により, 設計フローに従った各計算ルートから二次設計のチェッ クをすることも考えられる。なおこの場合, 地盤特性お よび各土質定数は, 地盤調查と各行政庁の資料から妥当 な值を推定する必要があろう。

\section{4 建物全体の二次設計と関連したくい基礎設計}

\section{(1) 建物 概 要}

用途：共同住宅

面 積: $10000 \mathrm{~m}^{2}$ (延)

階数: 地上 13 階

高 さ: $40 \mathrm{~m}$

基準階階高 : $2.75 \mathrm{~m}$

構 造 種 別：鉄筋コンクリート

考えるか，応力集中による局 部崩壊をどうするか, 上部構 造より下部構造の耐力を上げ るにはどうするか，等が二次 設計検討上必要になってく る。

付近の類似の地層での推定 地震動による動的 3 軸試験の 結果, 液状化の恐れは少ない という報告があるが，この例 では簡易法で検討した結果, 液状化の恐れは高いという結 果となった。また, 根切工事

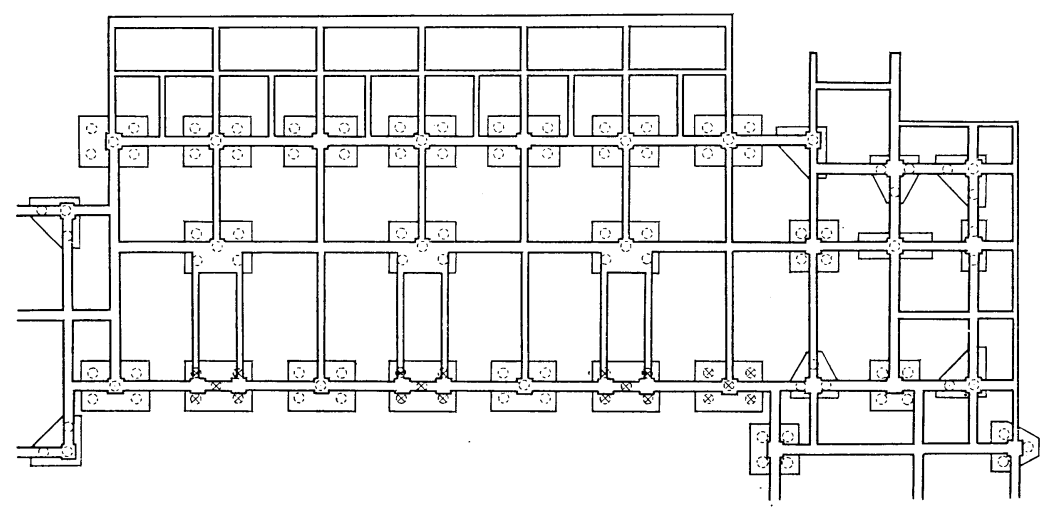

図一4.1 基礎伏図

Vol. 24, No. 8, Aug. 1986 
構造 概 要:

けた行方向 純ラー メン

はり間方向 連層壁 による耐震壁付ラー メン架構

(2) 建家全体の二次 設計方針

けた行方向：

はり曲げ降伏先行型

柱は 1 階柱脚にて曲 げ降伏（図一4.3）

はり間方向：

(1) 壁のせん断破壞 が先行しないよう にする。この時, 建物は転倒しない こととする。

(2)〈いの引抜け時を建家の転倒耐力とし, 転倒耐 力が(1)の上部躯体耐力以下でもよしとする（図一 4.4)。

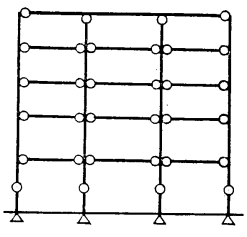

図-4.3

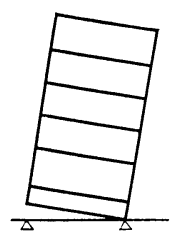

図-4.4

（3）二次設計に㧍ける基礎および基礎ばりの設計

1）上部躯体柱曲げ降伏時（けた行方向地震）は, 図 -4.5 (a)，(b) の降伏状㦔について, 1 階の保有水 平耐力を算定する。

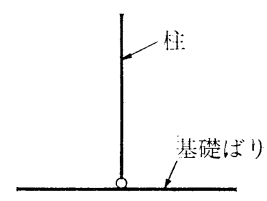

(a)

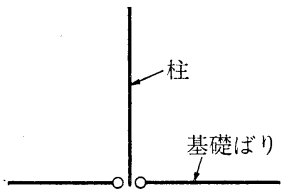

(b)

\section{図-4.5}

2）建家転倒時（はり間方向地震）は基礎ばり曲げ降 伏または, くい極限耐力による下記のせん断力に対 して，基礎および基礎ばりがせん断破壊しないよう にする(図一4.6)。

なお，建家転倒時とは，引張側のくいがすべて抜 けて建家全重量が圧縮側の通りのくいにかかった状 態とする。

(4) 二次設計におけるくいの設計

1）建家転倒時の圧縮側のくい反力は，〈いの極限耐

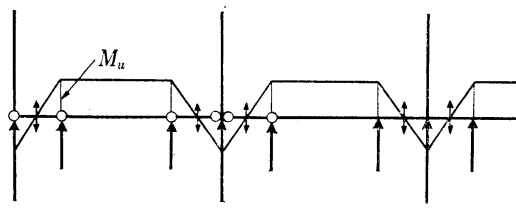

図-4.6

力以下とする。

2) くいの水平耐力は, 上部躯体の必要保有水平耐力 または転倒耐力以上とする。

なお，〈いの水平耐力は，各くい軸力に対する終 局曲げ耐力時のせん断力の累加とする。

(5) 結 果

上部躯体およびくいの保有層せん断力倸数 ( $D$ 值換 算) と $D_{s}$ 值との関係は以下のとおりである。

上部構造水平耐力 (けた行方向) $: 0.36, D_{s}=0.3$

上部構造水平耐力 (はり間方向) : $0.43, D_{s}=0.4$

はり間方向転倒耐力 : $0.3, D_{s}=0.4$

<い水平耐力: $0.44, D_{s}=0.4$

(6) 考 察

本設計例を通じて，下記のような点が今後の課題とし てあげられる。

1）コスト面で確実にアップする。

2）転倒時の基礎ばりの応力評価方法の確立が望まれ る。

おわりに

くい基礎の二次設計には，上部構造以上に難しい色々 な問題が存在し，調查・実験・研究は続けられているが なかなか明解な答が出てこない。このことは，地盤とい う構造材料が極めて複雑で, 再現できない材料であるこ とに起因しているものと思う。そのために他の構造材料 のように簡単に模型実験でその性状を確かめるというわ けにはいかないこととなる。

メキシコ地震の大災害は, かの地の超軟弱地盤に大い に関係するものであった。このような地盤における基礎 構造はいかにあるべきかという点に関し，われわれはい ま一度見直す必要がありはしないかと考えさせられるよ うな諸問題が提起された。またこの地震はいずれわが国 にも起こり得べき大震災の姿が目にちらちらし始めるよ うな巨大な教訓を残したものと思う。このことを肝に銘 じつつ本稿を終える。

\section{参 考 文 献}

1）杉村義広 : 建築基礎耐震設計の現状と問題点，コンクリ 一下工学, Vol. 22, No. 10, 1984.10

2）北後 寿 : 最近の建築基礎杭設計の動向, 基礎工, 1985 . 11 および' 86.1

3）大杉文哉ほか：杭基礎の 耐震設計上の諸問題, パネルデ イスカッション要約，建築雑誌，No. $1244,1986.3$ 